\title{
Public Administration and Lawsuit's Resolution: A Case Study and Trends in Brazilian Judiciary
}

\author{
Thiago Souza Araujo ${ }^{1,3}$, Silvio Dagoberto Orsatto ${ }^{3}$, Aires J. Rover ${ }^{2} \&$ Gertrudes A. Dandolini $^{2}$ \\ ${ }^{1}$ Associated Lecturer at Instituto Federal Catarinense de Educação Ciência e Tecnologia, Brasil \\ ${ }^{2}$ Professor at Engenharia e Gestão do Conhecimento Department, Universidade Federal de Santa Catarina, \\ Brasil \\ ${ }^{3}$ Ph.D. Candidate at Engenharia e Gestão do Conhecimento, Universidade Federal de Santa Catarina, Brasil \\ Correspondence: Thiago Souza Araujo, Universidade Federal de Santa Catarina, Campus Reitor João David \\ Ferreira Lima, bairro Trindade, CCJ, sala 327, Florianópolis, Santa Catarina, Brasil. E-mail: \\ araujo.thiago.souza@gmail.com
}

Received: March 25, 2016 Accepted: May 15, 2016 Online Published: October 30, 2016

doi:10.5539/par.v5n2p70

URL: http://dx.doi.org/10.5539/par.v5n2p70

\begin{abstract}
This paper aims to present improvements in Public Management on Brazilian judiciary. A qualitative theoretical-empirical study based on data sets and interviews provided by Brazilian Judiciary shows how specialization and multidisciplinary teams can affect the efficiency and efficacy in solving lawsuits. Innovations observed includes practices such as systemic view, multidisciplinary teams' adoption - co-production - applied to the public service. It is also shown long term planning and preventive practices that tends to avoid public service demand. Better results emerged when applied both specialization and multidisciplinary work. In this period the organizational unit observed dropped convictions amounts to a quarter of similar sized units on average. This means that State saved millions of Dollars - presented in local currency - in State judicial convictions that may now be spent in other areas such as education or infra-structure. Lawsuit resolution timeframe reduced from 729 to 60 days on average, median from 665 to 11 days. These observed results evidences that a lawsuit with a specialized and multidisciplinary team is more likely to improve quantitative and qualitative results.
\end{abstract}

Keywords: public management, Brazilian judiciary, systemic view, innovation at public organizations, multidisciplinary teams

\section{Introduction}

Brazil is a continental sized country in South America which adopts a presidential federative republic model. Federation is composed by 27 units: 26 states plus a federal district. Brazil also follows the "trias politica" principle, what means that State power is constituted by Executive, Legislative and Judiciary separately.

This work focus at Judiciary power, its courts and administration, approaching their efficacy and analyzing possible improvements in its organizational structure and operations based on data gathered. Judiciary power is responsible to judge lawsuits and to provide justice.

From this perspective, section 1.2 brings the study's theoretical background. Subsequently, section two explains the scientific methodology adopted at this work. Afterwards, section three explores the case study presenting information obtained from the field research such as interviews and dataset presentation. Section four transports a conclusive analysis about the information obtained from the data, as well as makes a relation with the context in a systemic manner.

Throughout data analysis, and management theory of specialization applied to State Judiciary the theme presents the trends and challenges to be faced by the Judiciary emphasizing that the systemic view may generate opportunity to solutions never before perceived creating outstanding solutions.

\subsection{Theoretical Foundations}

In Public Administration some technological advances have transformed organizational capabilities, as well as they transformed society along the years. It happened with previous technological revolutions: steam machine resulted in industrial revolution. Computer technologies have lead to information and communication 
technologies and a lot of impact in nowadays organizations.

The electronic document adoption a decade ago - and thus the judicial electronic process - made room for a series of organizational improvements at the Judiciary in Brazil.

\subsubsection{Technological and Social Backgrounds}

The information society and informational economy - based on complex relations - mediated by Information and Communication Technology (ICT) is the start point on this context. Electronic computers and ubiquitous electronic networks as described by Castells (1999) are considered the wider context for organizations nowadays The "Digital economy" concept developed by Tapscott (1996) and the commercial viewpoint of the new pattern of economic context presented by Evans and Wurster (2000) and also by Anderson (2006).

At public sector, Ferguson, Burford \& Kennedy (2013) argues that wider ICT context impacts in public sector innovation and effectiveness. These authors show the scarcity of public sector case studies that present organizational practices in this sense of new structures, in a more emergent fashion. Innovations at the public sector has its challenges (Schwella and Erwin, 2014; Mulgan, Geoff and Albury, 2003). Public sector has its specificities, since public sector deals with the collective, citizens, the public (Rainey, Hal and Bozeman, 2000; Hughes 2012).

The organizational holistic view helps to improve performance and service quality. Holistic view is intrinsically related to the systemic (interconnections) concept. Systemic view is a worldview based in the concepts of Von Bertalanffy (1956), Capra (1982; 2014) and Maturana and Varela (1987). Holistic approach means that the "whole is greater than the sum of its parts", it is the organic and systemic view. Organization is composed by systems, process, be it based on paper or computers. So, when you analyze a system, its behavior depends on the interactions among parts. So the organization. Systemic view is related to the complexity of systems, which assumes that systems most of times are not linear, specially organizations. The holistic approach may extent the understand of an organization to its surroundings. Thus in a public organization the participation of society is a way to apply this holistic view. When a public organization interacts with society to create a solution - be it a service or a product - it is called co-production (Whitaker, 1980; Boyle and Harris, 2009; Horne and Shirley, 2009).

Systems can be studied by feedback and iteration. The non-linear characteristic implies in the possibility of small changes to create a big impact. The emergence and convergence characteristics of systems as study units is drawn a limit - frontier - for the system and its environment. This is the principle behind higher efficiency of multidisciplinary groups, herein applied to the public service.

When systems are draft from individual perspective it fails (Bunge, 2003). Paradoxically, the interconnection provided by technology allows intellectual work specialization, which serves distinctly to a well distinguished work to Judges. So a Judge may be at the same time specialized and take advantage of scale gains and specialized knowledge, and at same time build a multidisciplinary team to take advantage of multidisciplinary perspective in a specialized field, as it will be shown afterwards.

From this point of view, some arguments in the systemic view of Capra (2014) deserves to be highlighted, such as, the necessary change of values from expansion to conservation, competition to cooperation, from domination to partnership. These points are worth to reflect specially in public sector.

\subsubsection{Specialization in Public Organizations and at Judiciary}

In Organizational Studies, Strategy and Structure are tied one another. As structure follows strategy (Chandler, 1962) strategy also follows structure (Hall and Saias, 1980). Anyway, strategy and structure interact with each other (Miller, 1987; Mintzberg 1990; Roberts and Greenwood, 1997). In Italy this organizational and institutional aspects was also approached by Carnevali and Di Cocco (2001).

Organizational structure and strategy making are interdependent as Miller (1987) affirms, adding that there is a reverse causality: strategy determines the design of structure as well structure influences later strategies and so on, similarly to Mintzberg (1991) and Lorino and Tarondeau (2006). So organizational forms must change to adapt to new contexts (Malhotra, 2000).

Thus, organization is designed from a perspective based on its mission, vision, targets, process, hierarchy, people's values, as well as a specific structure is designed and raised from the strategy. Through this idea, the structure supports strategy and strategy follows structure. Changes push structures, in a new cycle. Nevertheless, strategy and structure are tied one to another. Strategy, structure and culture are interconnected (Sattelberger, Thomas, 1996; Daft, 2006). Hereafter, for a fine performance, in order to catch up with new strategies, structure 
must be adjusted to new strategies.

Task specialization leads not only to better quantitative efficiency, but also to better qualitative efficacy, not merely in business but furthermore in public sector (Nylén, 2007). Damle (2005) report specifically the necessity to specialization in the actuation of Judges with a title worth to mention "Specialize the judge not the court" The referred paper highlighted the demand in this sense in United States of America and Germany. Wood (1996) also defends the idea of judge specialization, with a relevant alert such as, keeping the accountability above decisions. Other studies, however, reinforce the necessity to judiciary specialization (Baum, 2009). Anyway, innovations both in organizational structures and process - usually incorporating new technology - is known to affect performance, mostly positively (Gera and Wulong, 2004).

Finally, among the Judge's approach in health specialization, the present paper underlines a basic principle in the field of public health: prevention is better and cheaper than treatment to cure (World Health Organization, 2002). Prevention avoids the cost of treatment and improves life quality.

\section{Research Methodology and Design}

Research problem will be presented in section 2.1. This section also presents the basic hypothesis. This problematization leads to the research approach (2.2) as well as research instruments used to conduce the work (2.3). Afterwards it will be presented which courts are selected to be studied and why (section 2.4). So the research context will be explained (section 2.5).

\subsection{Research Question}

Judiciary as the provider of justice is a complex organization and its efficiency and efficacy is often questioned both in its efficiency and quality of service. Sometimes innovations - be it organizational, procedural or technological - emerges and raises again these question. With State Judiciary efficacy in quality and results as main question, the basic hypothesis is: changes at State judiciary lawsuit process with specialization will result in better outcomes in a qualitative sense.

\subsection{Research Approach}

This research work consists in applied research with field research, and so theoretical-empirical study. It is also hypothetical-deductive. Research design adopted is a mixed research qualitative-quantitative approach (Creswell, 2009; Hibert et al, 2014; Mason, 2006; Glaser, 2008 e Glaser, 2009). Johnson, Onwuegbuzie and Turner (2007, p. 120) explains that mixed research methods means the combination of qualitative and quantitative methods including data collection and data analysis in research project. At this way, different methodologies are complementary used to enhance the validity of findings. Downward and Mearman (2007, p. 6) calls the use of mixed qualitative and quantitative methodologies as a "triangulation". So, qualitative work based on observation and interviews were searched to understand and validate what quantitative results truly meant. This work is also exploratory, since there are not many studies about specialization at State Judiciary in Brazil, none found with the perspective used herein.

\subsection{Research Instruments}

Thus, "case study" method is presented with some quantitative data sets which are organized as contextualized information. Therefore, this study conduces unstructured and structured interviews to Judges, mainly to a specific Judge who is leading this new multidisciplinary approach to a specific theme: health lawsuits.

Since study's focus relies on innovative qualitative approach, interviews are conducted to understand improvements on justice service provided. It was conducted three unstructured interviews in different occasions and one structured interview with key topics to be presented - transcribed - in this paper. Lengthwise, it was compared quantitative data, obtained with judiciary information system, with the analysis developed along interviews and validated by the interviewed in what regard qualitative achievements. Some tools such as spreadsheets and Data Mining software were used to analyze the case.

\subsection{Sample Definition}

Since the study is conducted with the support of the higher administrative instance of Brazilian Judiciary - the National Council of Justice National and Brazilian Law of transparence affirms that anyone may have access to information about public organizations it took a simple administrative request to have access to all data set requested. The State Judiciary provided about all courts in Brazilian State Judiciary (Santa Catarina State). Lages "Public Court" Unit is the base reference in this Case study in the conducted analysis for the innovation in specialized team strategy adopted for this unit.

To adequately compare with other courts, it was selected courts inside Santa Catarina State with similar size. In 
Brazilian Judiciary system, all resources are allocated to courts basically accordingly to number of citizens on the city. Since Lages is among the ten most populated cities in Santa Catarina State it was choose the cities based on these criteria of the ten more populated. Another criterion is the existence of a specialized court in Public Court issues. It is worth to mention as a limiting factor that although existing data was supplied for the research, some data did not match quality requirements - completeness, consistency, correctness, precision, accuracy (Bobrowski, Marre and Yankelevich, 1999; Stuart, Wang e Zhu, 2009). Presented data in tables and charts achieved these requirements. So, based on these criteria, selected courts found were: Blumenau, Capital, Jaragua do Sul, Joinville, Palhoça, São José, and Tubarão. These courts are part of a State Judiciary system and a National Judiciary System.

\subsection{Case Study Context}

The Brazilian Judiciary is complex. For common citizens its organization is based in counties at regional level. Operationally Executive and Legislative powers have clearly 3 layers: - city (local layer), state (federative unit), and Federal (central government). For its turn, Judiciary Power has a slightly different structure: while cities and states are the same for executive and legislative, Judiciary has some thematic segmentation in its federal layer. At state (federative unit) level, there is a Central Court that composes the second layer, which is similar to the Executive and legislative. But at local layer it is not composed by cities. Instead it is composed by counties, that may embrace some cities in less populated areas. Judiciary (public) management has also its peculiarities: Counties have one judge as administrative responsible, but almost all Public administration is processed centralized by State Judiciary. So, in what regards administrative matters, counties work strictly at the operational level, while state Judiciary has overall management over judicial counties.

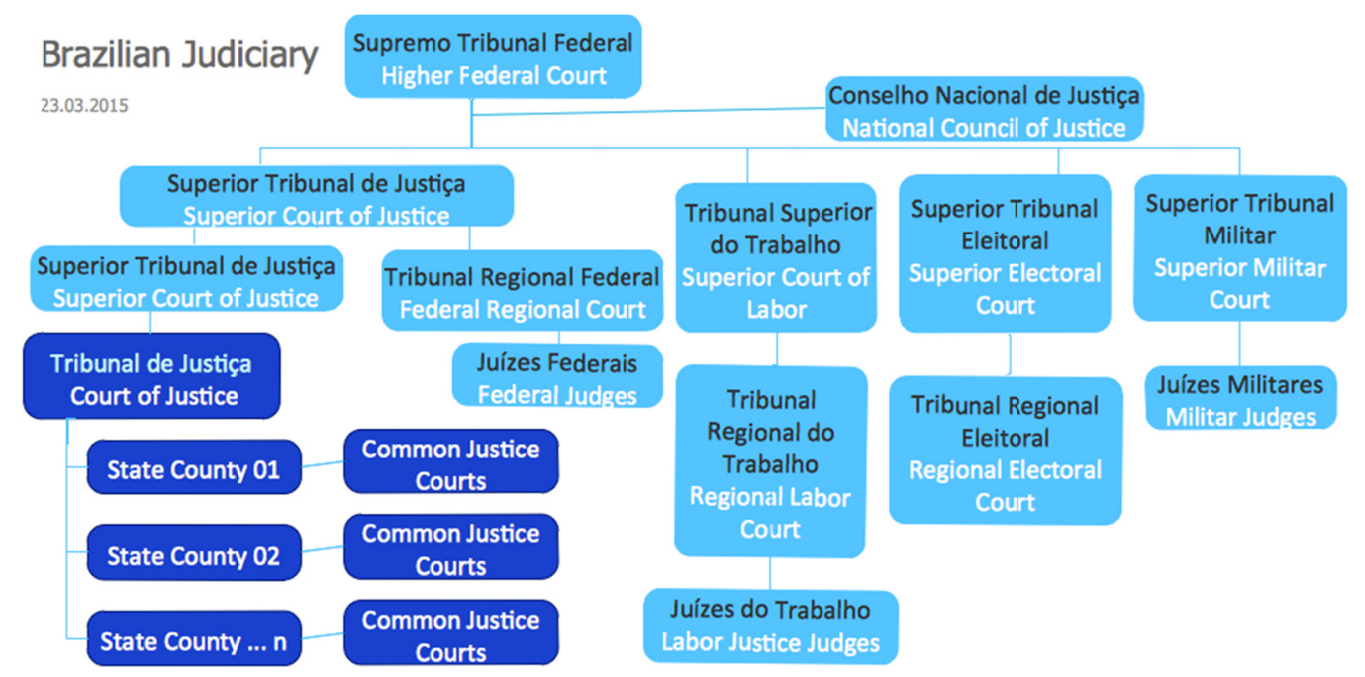

Figure 1. Brazilian Judiciary Structure. Source: Developed by the authors based on Brazilian Constitution and constitutional amendment no 45/2004

In this case study it will be presented lawsuits related to Public Health. Public health is a delicate issue. Constitutionally, in Brazil, State is responsible to provide health to population. Therefore, when a citizen suffers from a disease or situation in which the treatment is very expensive, he demands to the State, through the judiciary system, his right of health treatment.

Nonetheless, the diseases do not wait for the time of lawsuits processes. Each minute waiting for the justice is critical for patients with health problems. The more time passes, the smaller are chances to completely heal. As a consequence, treatment becomes even more expensive. For that reason, this kind of process is so critical.

A Judge facing this reality of several lawsuits about health against State, decided to take a new approach while ruling on. He realized a qualitative approach would give better life quality to patient and smaller costs to State. Thus he decided to form a multi-disciplinary team in the field of health and started to find alternative solutions to improve quality of treatment as well as more cost effective solutions. After some time, it was developed preventive actions along with public and non-for-profit organizations.

In this sense, innovation and creativity are absolutely important to find solutions which, at the same time, may save the citizen's life and also save costs to the Treasury. 
Therefore, in Santa Catarina State, at "Lages" (city name) county, one judge adopted a multidisciplinary team based in competencies in the field of health, composed by physicians, nurses, physiotherapists, Nutritionist, Occupational Therapist, Physical Educators.

The paper's authors during a research discovered this particular scenario and then decided to interview this Judge who was conducting this different multidisciplinary qualitative approach to wisely decide over judicial cases.

\section{Results: Overall Data}

The initiative started in the year 2007 but really took off in 2008. Lawsuits specifically about medicine and health treatment summed 541 lawsuits from year 2004 to 2015. About how lawsuit finished:

Table 1. Lawsuits results

\begin{tabular}{cccc}
\hline & Lawsuits & Convicted & \% Convicted \\
\hline State & 462 & 306 & $66.2 \%$ \\
City Hall & 462 & 233 & $67.1 \%$ \\
\hline
\end{tabular}

Source: Data obtained from the court, compiled by the authors

The state or city was convicted to pay the treatment in more than $50 \%$ of cases, since health is considered an assured constitutional right. So at open interviews it was clarified that in several cases the lawyers issue the lawsuits against all public spheres, Federal, State and local Governments.

Since competences may vary accordingly to the case (generally they are shared), in some situations one or two of the passive part is acquitted, that is why statistics shows something around $67 \%$ of Public sphere convicted. Specialized Judges says this share of responsibilities is confusing to citizens and their lawyers; they also believe it only makes things worse for planning. Anyhow, in practice, considering what was just explained, the real rate of public sector conviction is near $99 \%$.

\subsection{Findings: Innovation in Justice Approach}

After dealing with some distressing health lawsuit claims the Judge of Lages Court decided to improve his project by creating a support with a multidisciplinary team in year 2007. In the past years, many volunteers health specialists - participated. Today the multidisciplinary team is composed by professionals such as nutritionist, physical educator, occupational therapist, Psychologist, and physical therapist.

According to the official Court register's, the multidisciplinary team participated in lawsuits, on demand. Detailed data follows on table 2.

Table 2. Number of professionals involved in lawsuits solutions by specialty

\begin{tabular}{lc}
\hline \multicolumn{1}{c}{ Professionals } & Participation in Cases \\
\hline Nutritionist & 301 \\
Physical Educator & 9 \\
Occupational Therapist & 37 \\
Psychologist & 335 \\
Physical Therapist & 93 \\
\hline
\end{tabular}

Source: Data obtained from the court.

Beginning in 2005, most of cases (541) took place among the years of 2008 and 2014. The team was formed in between these years. In the search for better solutions for citizens, each specialist was called as needed. In order to understand this original approach, it is presented hereafter the Judge interview transcription, about aspects related to this new approach. This interview presented key questions and their answers. 
Table 3. Structured interview transcript

\begin{tabular}{ll}
\hline \multicolumn{1}{c}{ Question } & \multicolumn{1}{c}{ Interviewed Judged Answer } \\
\hline What was the motivation for & $\begin{array}{l}\text { The anguish of seeing people in need of urgent treatment. The time of process is } \\
\text { dhis new approach? }\end{array}$ \\
& $\begin{array}{l}\text { different of the time of the illness. When there is a cancer spreading in your body every } \\
\text { fast enough was devastating, even being strictly accordingly with the fastest possible } \\
\text { law process. They are humans suffering. It was clear that something should be done to } \\
\text { improve the justice effectiveness. }\end{array}$
\end{tabular}

How did the multidisciplinary strategy started?

How did the project progress to gain the current impact and support?

What is the innovation?

We started by looking for health specialist to obtain advice on some specific situations. Then I realized that they were interested in helping. Subsequently, the specialists started to meet with me on a regular basis.

Non-for-profit institutions decided to know our work, they liked and gave us support to the initiative. Then based on the most common health problems we started to develop prevention campaigns in partnership with these non-for profit organizations and even public sector at the local Government level.

The focus in to provide justice in a wider sense. The process is entirely based in the law, but goes beyond to read the lawsuit documents. We pay attention during the hearings with citizens, talk to them and understand their health problems. When we understand the problem and we have specialists to help, it is possible to find better solutions. By knowing the most common problems that appears in Justice it is possible to communicate to society the importance of prevention. Prevention will avoid more people to suffer with these common health problems.

Did or did not the Judge specialization help to find this new approach?

It was crucial because when you specialize in a theme you get experienced in this theme. Things start to repeat in front of you and this makes you think how to avoid some problems faced by many people or how to provide better justice to citizens.

Which are the results so far? Citizen and family gave positive feedback, because they felt the attention of Justice. This was the first result and the first sign that results worth the effort. So the results are a better justice for society, and also a considering drop in treatment costs. Since State spends less in treatments, the State can invest more in prevention and also in another fields such as education, infrastructure and other critical areas in Brazil.

We do not have tracked the exact amount of cost reduction to the State with procedures and medicine, but we will start to do that. For now, we know that the cost reduction is absolutely significantly. Sometimes the solution has a small cost reduction, sometimes is the same as claimed in the process, but there are cases in which we saved $50 \%$ up to $90 \%$ of costs with alternative - and better - treatment.

With this work, did the speed of solving health lawsuits changed in any way?

Qualitatively what comes next?
Until the year of 2012, judges needed to send this kind of lawsuit to federal justice, which was not logical and made the speed of process a lot slower. Now, with this new approach, the process changed in a way lawsuits are solved much faster.
Santa Catarina State's health department spends only 3\% of its budget to basic treatment and prevention; most of budget is spent in hospitals. Some factors as stress and increase in population aging results in a tendency of rise in health problems in population. Therefore, it is mandatory the long run planning and work on prevention. We are already working on that.

Source: primary.

In this project Judge reads the lawsuits and separates some questions to take to the multidisciplinary team. This team analyzes the technical health information in lawsuits to find alternative and better solutions. It was also developed a series of committees like the committee of medicine.

An iconic case reported by the Judge happened in a process in which the patient claimed for a kind of surgery in a private institution in an expensive clinic ( $R \$ 95000.00)$ in a city at $365 \mathrm{~km}$. Investigating the situation the multidisciplinary team working together were able to find a vacancy earlier in a public hospital for a fraction of 
that cost $(\mathrm{R} \$ 5$ 000.00), at State Capital, $150 \mathrm{~km}$ closer, with a very qualified surgeon. This is an example of a better, faster and cheaper solution.

Solutions like that are presented to the patient and his lawyer in a hearing with Judge, with participation of multidisciplinary team members.

Patients and their lawyers always accept a better solution. This is an example of how justice can be more effective thinking in the facts that are behind the written lawsuit.

Nonetheless, the most important achievement of this judge is the qualitative approach to the lawsuit judge process, what implies in better response directly to the citizen in a humanized technique. According this Judge, the patient's wellbeing and health makes difference, and this is shown to citizen when he most need help of justice.

This methodology became possible since the judge became specialized in this kind of case. Before, due to organizational structure and labor division, this Judge had to work with a wide range of themes.

Now this Judge and his multidisciplinary team started to interact with other institutions/organizations. The State Government health department started to cooperate and debate health questions with them in the sense of standardization of procedures and campaigns of prevention. Hereupon in picture 01 it may be observed one of these meetings to debate these questions.

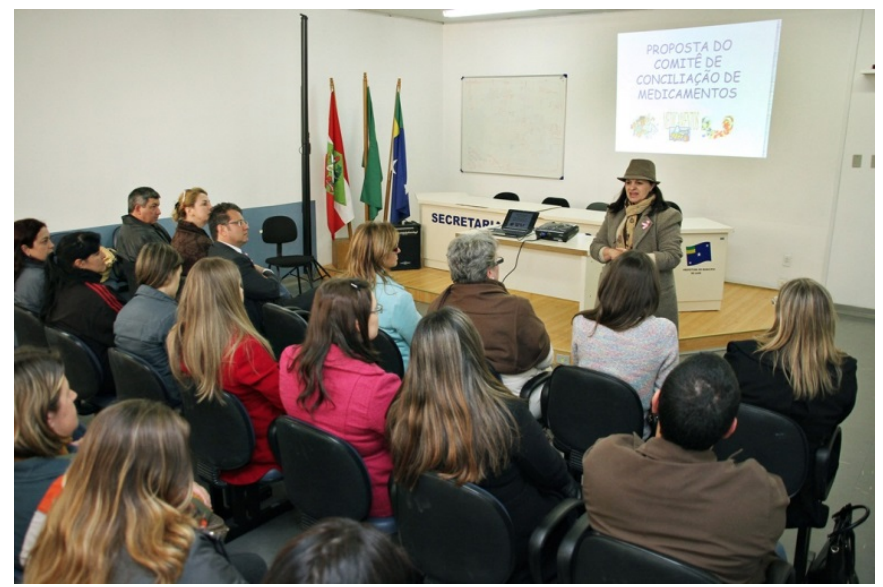

Picture 1. Workshop capacitation for Pharmacy employees at Lages city

Source: Lages Court archive, provided by the Judge.

These Judge's team actions was noticed by the regional media appearing in the newspapers. 


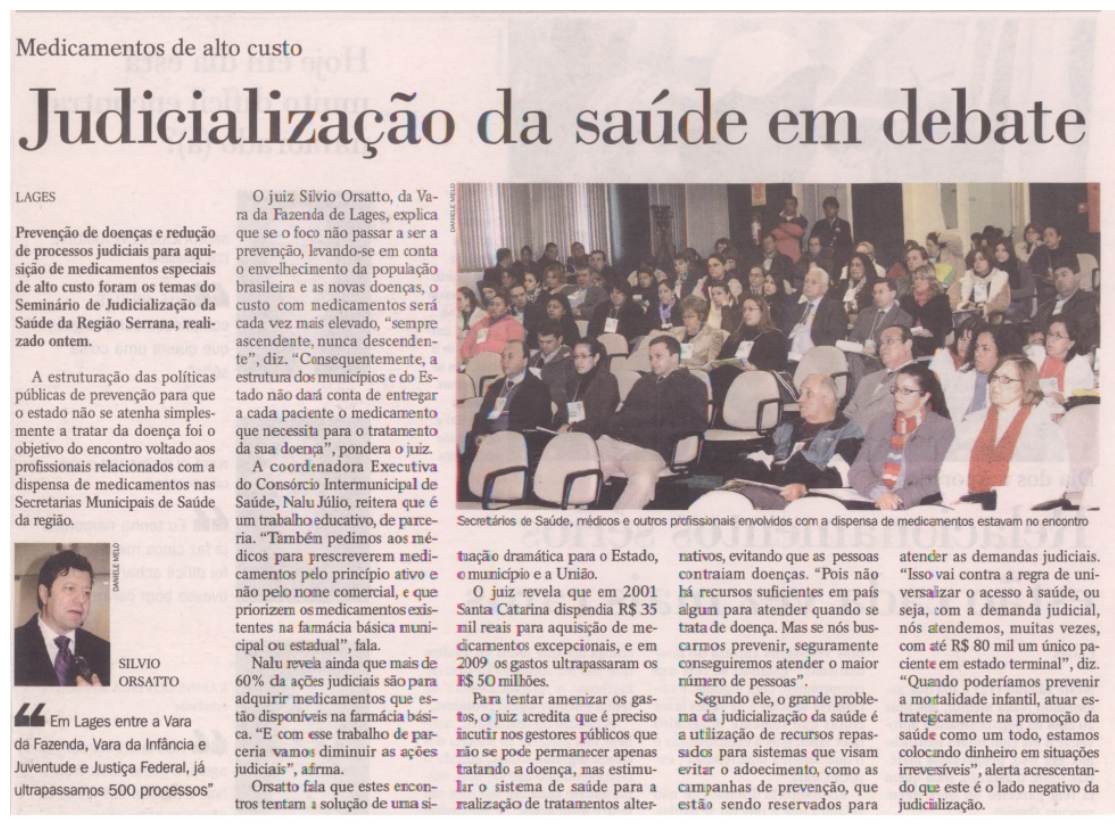

Picture 2. Newspaper with a journalistic matter, title: "Judicialization" of health treatment Source: Correio Lageano Newspaper.

Other Newspaper journalistic headline: "Health practices in Lages region are featured topic in Santa Catarina State".

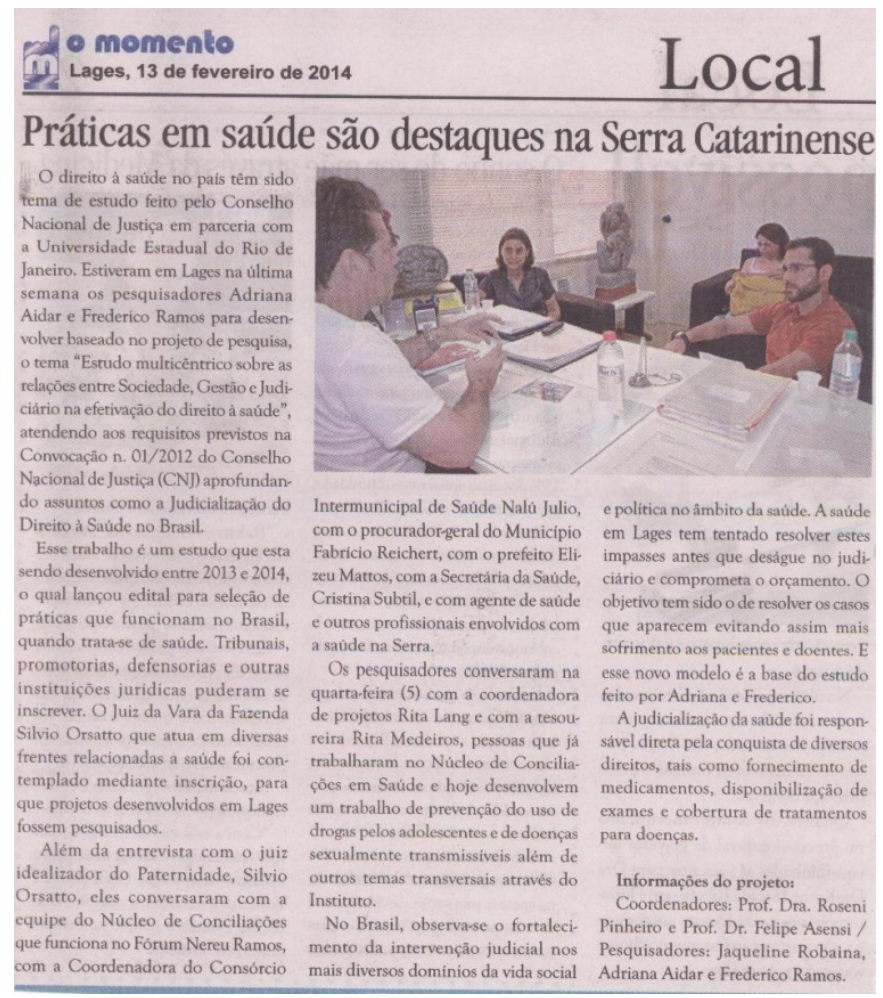

Picture 3. Newspaper with a journalistic matter, title: health actions treatment Source: "O Momento" Newspaper, Judge 's personal collection. 
According with the judge interviewed, on beginning of 2008 with this multidisciplinary team, the initial impact was the increase in number of process at court of Lages, because patients and lawyers discovered that justice was really working.

One of multidisciplinary team's action organized by the Judge was to create an equivalence table of medicine from different Manufacturers. This was a very simple solution that allowed cheaper treatment and equally effective solutions. It only was legally possible because of medical specialist authorization formally as a judicial expert. Initiatives like that were debated with health system and turned as standard procedure, thus it was one of the causes of lawsuit processes to drop in 2012 and 2013. So as citizens had his problem solved they do not need anymore to claim it judicially.

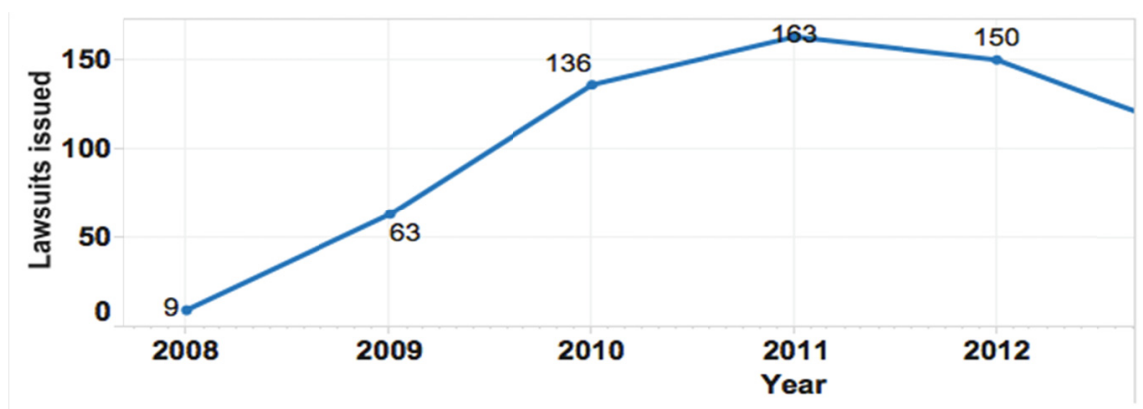

Graph 1. Number of lawsuits per year at the court studied

Source: Official data provided by the Judge and compiled by the authors.

Above, the specific lawsuits issued, regarding health theme, against the State. In these cases, the State in Brazil has the constitutional obligation to provide treatment and medicine to assure the "right to life" when the citizen cannot afford it.

This data was analyzed with all interviewed. Data displays what the judge in fact reported. When citizens received a new approach from the justice other citizens came looking for assistance in the way to assure their rights as well. The effect of demand size inertia (Stanko, Bohlmann and Molina-Castillo, 2013), or pent-up demand, may explain significantly the increase from 2008 to 2011.

Thereupon, it was identified two main factors that contributed effectively to decline the tendency in opening new lawsuits. The first one relates to some patterns established with local and state Government which assured access to medicine and treatment avoiding the necessity to look for the Judiciary. That is effective justice, when what must be done is simply done without the need of a lawsuit.

Secondly, campaigns on prevention started to give results to prevent the most common health problems. In the sequence there is a subset of the collected dataset with lawsuits per court. In this dataset it is possible to observe the number of lawsuits issued per year in similar sized courts in Santa Catarina State Judiciary: 
Table 4. Number of lawsuits per year at the studied courts

\begin{tabular}{|c|c|c|c|c|c|c|c|c|}
\hline & & 2008 & 2009 & 2010 & 2011 & 2012 & 2013 & 2014 \\
\hline Capital & Lawsuits & 11,0 & 84,0 & 116,0 & 98,0 & 204,0 & 234,0 & 358,0 \\
\hline Lages & Lawsuits & 9,0 & 63,0 & 136,0 & 163,0 & 150,0 & 107,0 & 90,0 \\
\hline Tubarão & Lawsuits & 120,0 & 66,0 & 70,0 & 142,0 & 99,0 & 56,0 & 56,0 \\
\hline Chapecó & Lawsuits & 19,0 & 37,0 & 61,0 & 58,0 & 78,0 & 112,0 & 117,0 \\
\hline Blumenau & Lawsuits & 5,0 & 41,0 & 32,0 & 46,0 & 53,0 & 73,0 & 130,0 \\
\hline Săo José & Lawsuits & 8,0 & 8,0 & 40,0 & 53,0 & 39,0 & 23,0 & 32,0 \\
\hline Joinville & Lawsuits & 11,0 & 8,0 & 18,0 & 16,0 & 21,0 & 32,0 & 53,0 \\
\hline Palhoça & Lawsuits & 8,0 & 36,0 & 24,0 & 25,0 & 23,0 & 17,0 & 11,0 \\
\hline $\begin{array}{l}\text { Jaraguá } \\
\text { do Sul }\end{array}$ & Lawsuits & & 8,0 & 31,0 & 25,0 & 21,0 & 24,0 & 22,0 \\
\hline
\end{tabular}

Source: Official data provided by the Judge and compiled by the authors.

Graphically it may be seen the comparison to other similar courts in the State Judiciary in graph 02.

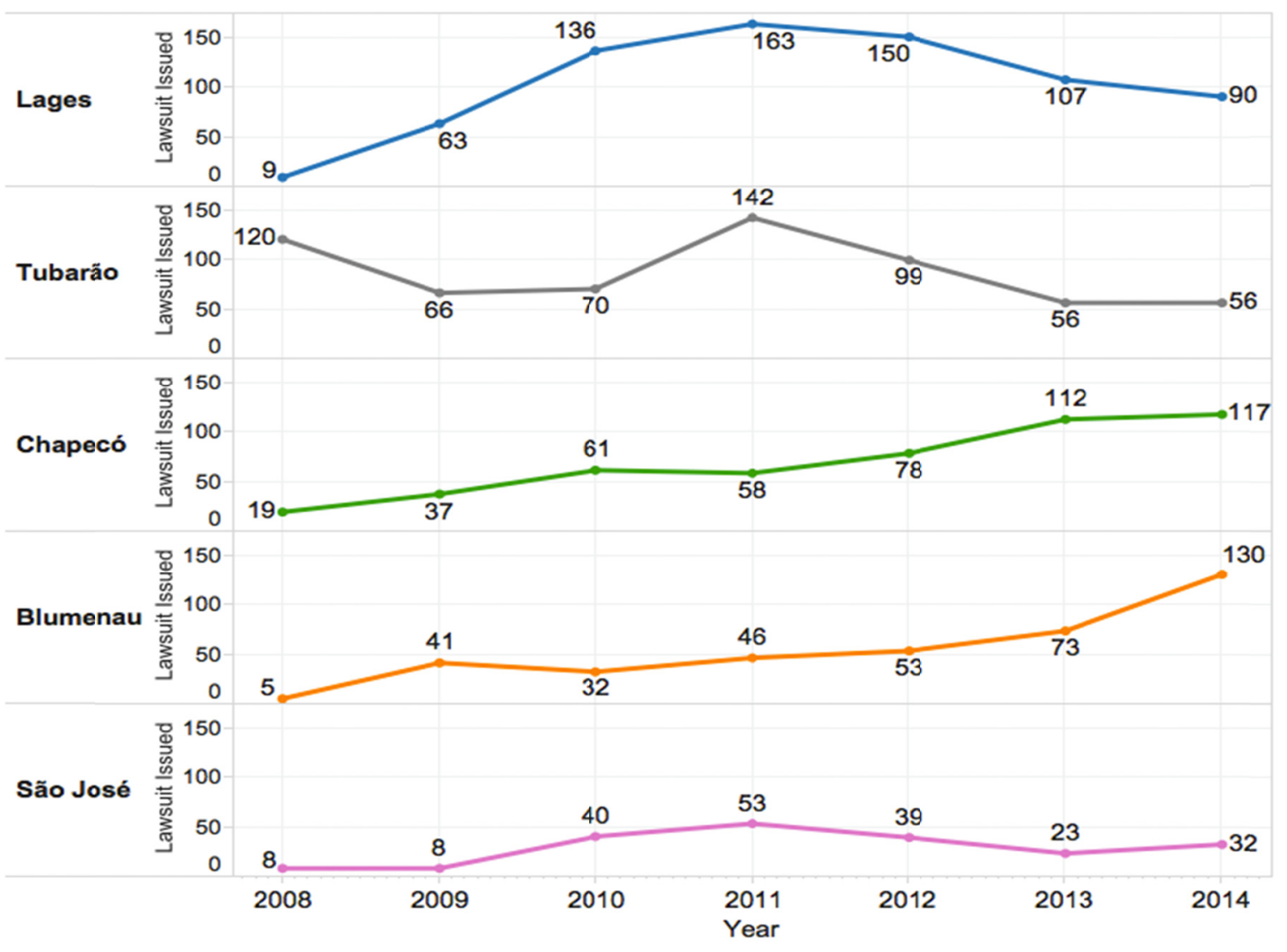

Graph 2. Number of lawsuits per year issued in similar sized courts at SC State Judiciary

Source: Official data provided by the Judge and compiled by the authors.

Although there is also specialization in cases against state, while Lages presents a tendency of stabilization - or a slight tendency to reduce new lawsuits - the tendency in most Brazilian's courts is to increase the number of lawsuits. 
Supplementary relevant data is the amount of resources addressed to urgent treatment. In the Court of Lages - as well as in other courts - the total amount follows the tendency of total case numbers as may be seen in Graph 03 compared to the two previous graphs.

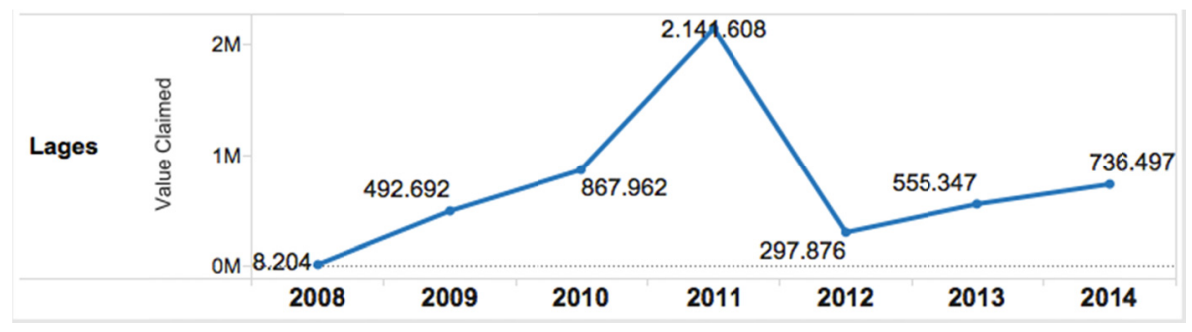

Graph 3. Amount of value claimed in lawsuits per year at Court of Lages

Source: Official data provided by the Judge and compiled by the authors.

Obtained data presented in table 05 shows the number of both lawsuits issued and values claimed in similar sized Courts at SC State Judiciary.

Table 5. Number of lawsuits and amount claimed per year issued in similar sized courts in SC State Judiciary

\begin{tabular}{|llrrrrrrr}
\hline \multirow{2}{*}{ Lages } & 2008 & 2009 & 2010 & 2011 & 2012 & 2013 & 2014 \\
& Lawsuits & 9 & 63 & 136 & 163 & 150 & 107 & 90 \\
& Value Claimed & 8.204 & 492.692 & 867.962 & 2.141 .608 & 297.876 & 555.347 & 736.497 \\
\hline \multirow{2}{*}{ Tubarão } & Lawsuits & 120 & 66 & 70 & 142 & 99 & 56 & 56 \\
& Value Claimed & 665.721 & 207.114 & 451.096 & 866.480 & 650.560 & 619.447 & 1.433 .552 \\
\hline \multirow{2}{*}{ Chapecó } & Lawsuits & 19 & 37 & 61 & 58 & 78 & 112 & 117 \\
& Value Claimed & 135.436 & 181.734 & 1.129 .028 & 940.765 & 857.878 & 2.440 .434 & 4.752 .876 \\
\hline \multirow{2}{*}{ Blumenau } & Lawsuits & 5 & 41 & 32 & 46 & 53 & 73 & 130 \\
& Value Claimed & 61.000 & 738.469 & 842.554 & 500.879 & 852.219 & 1.637 .970 & 3.833 .211 \\
\hline \multirow{2}{*}{ São José } & Lawsuits & 8 & 8 & 40 & 53 & 39 & 23 & 32 \\
& Value Claimed & 288.788 & 32.950 & 390.662 & 686.625 & 1.153 .070 & 3.833 .418 & 1.009 .606
\end{tabular}

Source: Official data provided by the Judge and compiled by the authors.

This information and the tendencies are better visualized in graph 04 : 


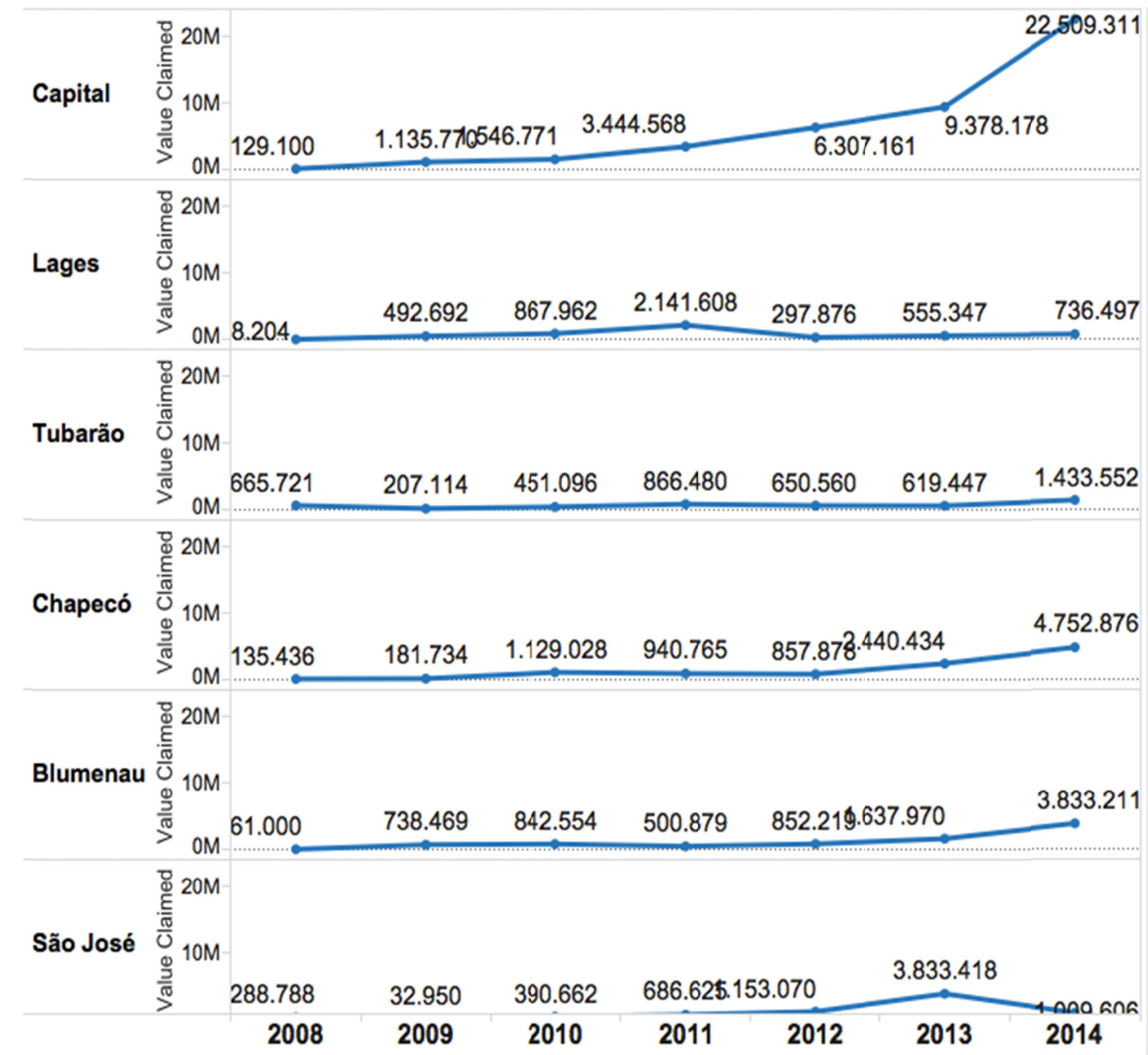

Graph 4. Number of lawsuits and amount claimed per year issued in similar sized courts in SC State Judiciary

Source: Official data provided by the Judge and compiled by the authors.

It may be observed that while the Court of Lages is facing claims about R $\$ 0.7$ million, similar Courts are in the range of $\mathrm{R} \$ 1.5$ million to $\mathrm{R} \$ 4.7$ million. These number are related to the Value Claimed, remembering that other solutions found by the multidisciplinary team are not taken in account till now.

Regarding the average time of process, the open interview reveals two opposite effects. There is a slightly increase in time to judge a lawsuit due to planning, organizing team and interaction with society. The second effect was the reducing in time due to the specialization team, which implied in qualitative improvements that saved time such as a support team, specified procedures in the specific theme.

Surely other minor conjectural factors also affected the data set. Nevertheless, the tendency to reduce process time is well observed. Another argument made clear: the reducing time effect tends to overcome the first stage increase time - effect in the mid and long run, as data shows. This effect may be clearly observed in Graph 05 below, which presents the average number of days a lawsuit consumed to reach a verdict. 


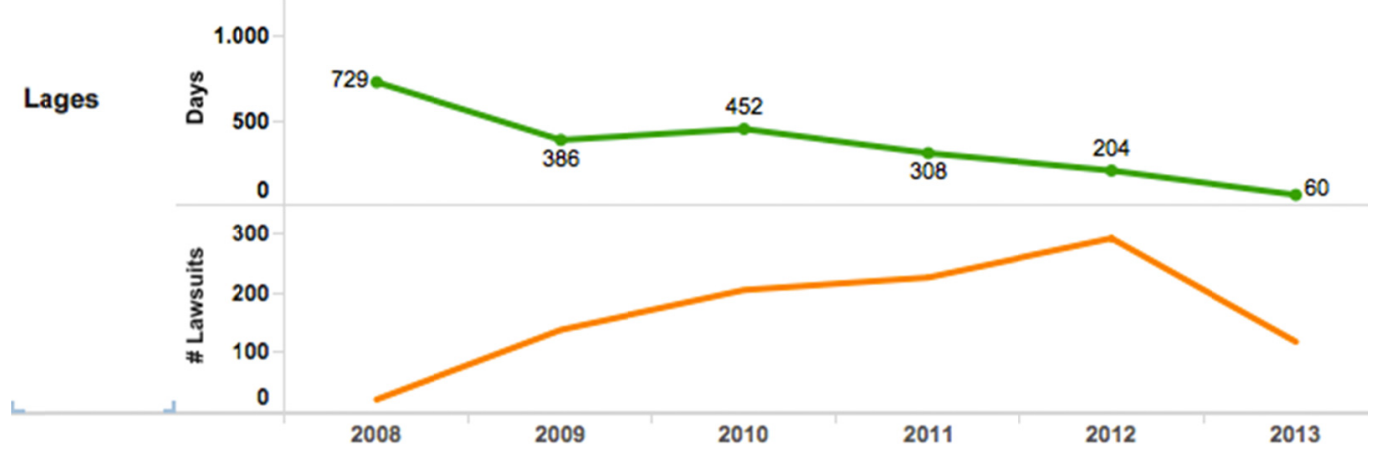

Graph 5. Average timeframe from lawsuit register to sentence at Lages Court

Source: Official data provided by the Judge and compiled by the authors.

Data obtained shows that similar sized courts - also with specialization - have as well as Lages, reduced time to sentence. There is a large set of variables and factors that affected this phenomenon. Specialization itself triggered other factors. From 2012-year onward health theme specialized State Judges convinced Federal Justice that it was unnecessary the obligation to send lawsuit process to federal level. This fact reduced lawsuit time in more than one hundred days the time to sentence.

Table 6. Average time lapse from lawsuit register to sentence in Lages Court and similar sized Courts

\begin{tabular}{|l|rrrrrr|} 
& \multicolumn{7}{|c|}{ Average Days to Sentence } \\
\hline Blumenau & 2008 & 2009 & 2010 & 2011 & 2012 & 2013 \\
\hline Capital & 466 & 342 & 367 & 275 & 115 & 24 \\
Chapecó & 785 & 662 & 545 & 438 & 175 & 24 \\
Joinville & 1.162 & 571 & 508 & 401 & 251 & 70 \\
Lages & 767 & 429 & 315 & 276 & 152 & 33 \\
Palhoça & 729 & 386 & 452 & 308 & 204 & 60 \\
São José & 995 & 462 & 508 & 438 & 260 & 42 \\
Tubarão & 990 & 536 & 438 & 376 & 218 & 45 \\
\hline \hline
\end{tabular}

Source: Official data provided by the Judge and compiled by the authors.

Besides average measure, data was analyzed using median, because it better represented the time consumed by most of lawsuits in days to sentence. This information is available in graph 06

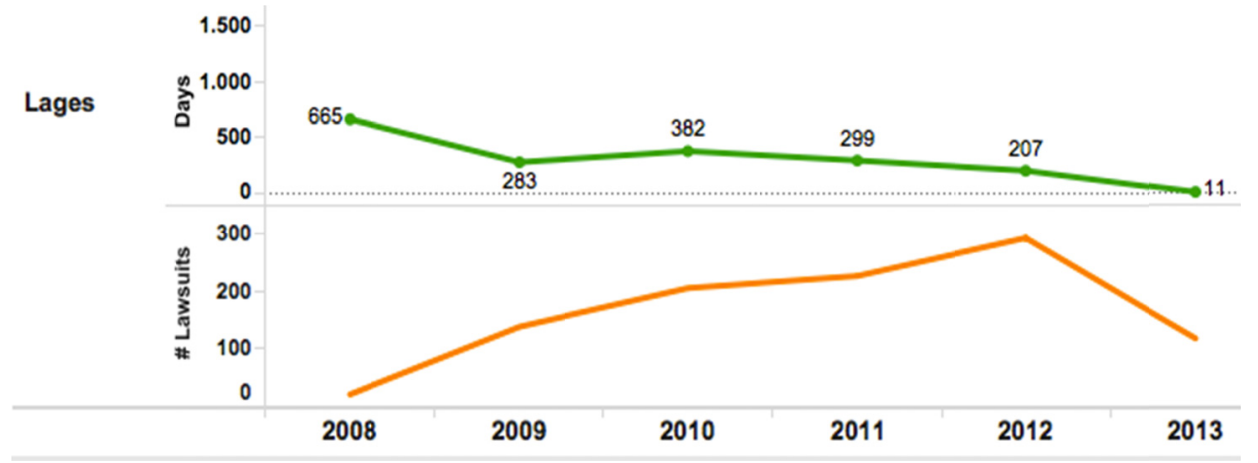

Graph 6. Average time lapse from lawsuit register to sentence in Lages Court and total amount of lawsuits Source: Official data provided by the Judge and compiled by the authors. 
The analyzed data confirmed the perception reported by the judge interviewed: the median lower time represents reality better than average measurement. Median evidenced also the increasing in process speed in 2013, specially when compared to other similar courts, as it may be observed in table 07 .

Table 7. Average timeframe from lawsuit register to sentence in Lages Court and similar sized Courts

\begin{tabular}{lrrrrrr} 
& 2008 & 2009 & 2010 & 2011 & 2012 & 2013 \\
\hline Blumenau & 215 & 168 & 190 & 158 & 14 & 2 \\
Capital & 738 & 672 & 454 & 415 & 59 & 3 \\
Chapecó & 1.591 & 394 & 482 & 346 & 275 & 15 \\
Joinville & 614 & 227 & 74 & 155 & 70 & 6 \\
Lages & 665 & 283 & 382 & 299 & 207 & 11 \\
Palhoça & 1.186 & 198 & 460 & 470 & 310 & 12 \\
São José & 1.053 & 531 & 239 & 272 & 194 & 35 \\
Tubarão & 1.315 & 956 & 687 & 373 & 199 & 77 \\
\hline
\end{tabular}

Source: Official data provided by the Judge and compiled by the authors.

Quantitatively Lages' Court follows the same pattern of similar sized - and so with some degree of specialization - but it is slightly outperforming them. Additional data that are significant, in terms of quantitative results, are unfortunately not registered until now. The circumstance of money saved by the Government in health treatment is one of this additional data, thanks to some alternative medical procedure or medicine found by the multidisciplinary team.

However, the most important innovation found is a set of qualitative aspects such as speediness in Justice answering patient's problems in hearings, or even preventing lawsuits by the State effectiveness in providing needed medicine as well as prevention programs in partnership with civil society (co-production), Government engagement and multidisciplinary teams. All these facts result in a better life quality to patients and therefore to citizens. Thus, they result in a real qualitative improvement and as a result implies in higher judiciary effectiveness. This quality improvement in service providing was allowed in first instance by the Judge specialization and the consequent deeper comprehension of specific themes such as public health.

This is Public Administration systemic view applied to the judiciary system. The multidisciplinary team is related in the interview as an effective alternative means to find resolution. Sometimes the medicine asked by the patient at the lawsuit is rare or difficult to obtain. In these cases, the entire multidisciplinary expert team is mobilized to look for that medicine or to find one effective alternative.

In this sense the State Judiciary created a State commission for cases of health lawsuits that are linked to the National Council of Justice.

\section{Discussion and Final Remarks}

A relevant aspect in Public Administration was observed: creativity and multidisciplinary teamwork with systemic view lead to innovative and effective solutions.

Information obtained from both interviews and quantitative data sets presented specialization as a source of better understanding of the overall situation in Public health lawsuits. This sense of systemic view and knowledge was able to stimulate innovation and made possible improvements, subsequently effectiveness emerged.

This new approach to lawsuit resolution has shown that although quantitative results are only slightly better, qualitative results such as quality of life for citizens, alternative medicine or treatment revealed to be far superior in the sense of human view of justice. Those observed innovations on Public Sector ended up leading to a set of preventive actions.

One additional positive side effect is the decreasing number of judicialization in the last years - after pent-up demand effect - according to data available. It was concluded by the judged and researchers that this fact happened because some of the solutions in public health system could be adopted to other cases without the necessity to call the judiciary. This was a gain for all citizens which had a solution established. This was also a gain for the justice that had less lawsuits to be judged. So it is for lawyers, that may dedicate their time to more challenging cases, not to mention the State that had lower costs. 
The basic hypothesis that changes in the State judiciary lawsuit process with specialization obtaining better results in the qualitative sense revealed to be true. Not only by the quality of decisions itself, but beyond that, by the specialization systemic and proactive view, and other actions that leaded to more effectiveness in providing Justice to the point of avoiding judicialization. In this sense justice has been co-produced with society.

A trend that arises from this case study is the possibility to replicate this successful model to other subjects at the judiciary system. Specialization is crucial for that purpose, since it is an enabler factor. Judges who magistrate over several different matters simply cannot by themselves invest time in systemic view, alternative solutions or practically any significantly way to improve effectiveness, they need focus and they need a team.

A different trend that may be considered in other themes is the necessity of a decentralized governance models. These governance models may be more effective, especially in cases involving higher amounts of money and power.

Nevertheless, challenge is how to promote public planning to prevent judicialization. Prevention is clearly much cheaper, but governments in Brazil unfortunately focus on the short run due to electoral schedule perspective.

Therefore, building multidisciplinary teams, promoting professionalization of some sectors by contracting experts in their respective fields - health professionals, managers, lawyers, economists, engineers and so on - to work on planning and prevention is really beneficial and challenging.

\section{References}

Anderson, C. (2006). The long tail: Why the future of business is selling less of more. Hyperion.

Baum, L. (2009). Probing the Effects of Judicial Specialization. Duke Law Journal, 1667-1684.

Bobrowski, M., Marre, M., \& Yankelevich, D. (1999): A Homogeneous framework to measure data quality. In: International conference on Information Quality, 7., 1999, MIT. Proceedings. Cambridge: MIT, 1999. p.115-124.

Boyle, D., \& Harris, M. (2009). The challenge of co-production. London: New Economics Foundation.

Bunge, M. (2003). Emergence and convergence: Qualitative novelty and the unity of knowledge. University of Toronto Press.

Capra, F. (1982). The Turning Point: Science. Society and the Rising Culture, Wildwood House, London.

Capra, F., \& Luisi, P. L. (2014). The systems view of life: a unifying vision. Cambridge University Press. http://dx.doi.org/10.1017/cbo9780511895555

Carnevali, D., \& Di Cocco, M. C. (2001). An innovation process embedded in a strict institutional setting: ICT in the Italian judicial system. Justice and Technology in Europe: How ICT is Changing the Judicial Business (2001): 197-217.

Castells, M. (1999). La era de la información: economía, sociedad y cultura (Vol. 1). siglo XXI.

Chandler, A. D. (1962). Strategy and Structure: chapters in the history of the industrial enterprise. Cambridge/Mass.

Creswell, J. W. (2009): Research design: Qualitative, quantitative, and mixed methods approaches. Sage publications.

Daft, R. (2006). Organization theory and design. Cengage learning.

Damle, S. V. (2005). Specialize the Judge, Not the Court: A Lesson from the German Constitutional Court. Virginia Law Review, 1267-1311.

David, F. R. (2002). Strategic Management: concepts and cases (9th ed.). Prentice Hall.

De Souza, M. A. D. (2013). The Brazilian Model of Precedents: A New Hybrid Between Civil and Common Law? Doctoral dissertation, King's College London (University of London).

Downward, P., \& Mearman, A. (2007). Retroduction as mixed-methods triangulation in economic research: reorienting economics into social science. Cambridge Journal of Economics, 31(1), 77-99. http://dx.doi.org/10.1093/cje/bel009

Evans, P., \& Wurster, T. S. (2000). Blown to bits: How the new economics of information transforms strategy. Harvard Business Press.

Gera, S., \& Gu, W. L. (2004). The effect of organizational innovation and information technology on firm performance. International Performance Monitor, 9, 37-51. 
Glaser, B. (2008). Qualitative and Quantitative Research. The Grounded Theory Review, 7(2), 1-17.

Glaser, B. G., \& Strauss, A. L. (2009). The discovery of grounded theory: Strategies for qualitative research. Transaction Publishers.

Hall, D. J., \& Saias, M. A. (1980). Strategy follows structure!. Strategic Management Journal, 1(2), 149-163. http://dx.doi.org/10.1002/smj.4250010205

Hibbert, P., Sillince, J., Diefenbach, T., \& Cunliffe, A. L. (2014). Relationally reflexive practice a generative approach to theory development in qualitative research. Organizational research methods, 17(3), 278-298. http://dx.doi.org/10.1177/1094428114524829

Horne, M., \& Shirley, T. (2009). Coproduction in public services. UK Cabinet Office.

Hughes, O. E. (2012). Public management and administration. Palgrave Macmillan.

Johnson, R. B., Onwuegbuzie, A. J., \& Turner, L. A. (2007). Toward a definition of mixed methods research. Journal of mixed methods research, 1(2), 112-133. http://dx.doi.org/10.1177/1558689806298224

Lorino, P., \& Tarondeau, J.-C. (2006). De la stratégie aux processus stratégiques. Revue française de gestion, (1), 307-328.

Madnick, S. E., Wang, R. Y., Lee, Y. W., \& Zhu, H. W. (2009, June). Overview and Framework for Data and Information Quality Research. ACM Journal of Data and Information Quality, 1(1).

Malhotra, Y. (2000). Knowledge management and new organization forms: A framework for business model innovation. Knowledge management and virtual organizations, 2-19. http://dx.doi.org/10.4018/978-1-930708-65-5.ch001

Mason, J. (2006). Mixing methods in a qualitatively driven way. Qualitative research, 6(1), 9-25. http://dx.doi.org/10.1177/1468794106058866

Maturana, H. R., \& Varela, F. J. (1987). The tree of knowledge: The biological roots of human understanding. New Science Library/Shambhala Publications.

Maturana, R. H., \& Varela, G. (1995). Francisco. A árvore do conhecimento. Campinas: Editorial Psy II.

Miller, D. (1987). Strategy making and structure: Analysis and implications for performance. Academy of management journal, 30(1), 7-32. http://dx.doi.org/10.2307/255893

Mintzberg, H. (1979). The structuring of organization: A synthesis of the research. Prentice-Hall.

Mintzberg, H. (1983). Structure in fives: Designing effective organizations Prentice-Hall. Englewood Cliffs, NJ.

Mintzberg, H. (1991). The structuring of organizations. In Mintzberg, H., \& Quinn, J. B. (Eds.), The strategic process: concepts, contexts, cases (2nd ed. cap. 6, p. 330-350). Prentice- Hall.

Motta, Paulo Roberto de Mendonça. (2013). O estado da arte da gestão pública: introdução. Revista de Administração de Empresas, 53(1), 82-90. http://dx.doi.org/10.1590/S0034-75902013000100008

Mulgan, G., \& Albury, D. (2003). Innovation in the public sector. Oakland University. Retrieved from http://www.sba.oakland.edu/faculty/mathieson/mis524/resources/readings/innovation/innovation_in_the_pu blic_sector.pdf

Nylén, U. (2007): Interagency collaboration in human services: Impact of formalization and intensity on effectiveness. Public Administration, 85(1), 143-166. http://dx.doi.org/10.1111/j.1467-9299.2007.00638.x

Rainey, H. G., \& Bozeman, B. (2000). Comparing public and private organizations: Empirical research and the power of the a priori. Journal of public administration research and theory, 10(2), 447-470. http://dx.doi.org/10.1093/oxfordjournals.jpart.a024276

Roberts, P. W., \& Greenwood, R. (1997). Integrating transaction cost and institutional theories: Toward a constrained-efficiency framework for understanding organizational design adoption. Academy of Management Review, 22(2), 346-373.

Sattelberger, T. (1996). Die lernende Organisation im Spannungsfeld von Strategie, Struktur und Kultur. In Die lernende Organisation (pp. 11-55). Gabler Verlag. http://dx.doi.org/10.1007/978-3-663-05812-0_1

Schwella, E. (2014). Inovação no governo e no setor público: desafios e implicações para a liderança. Revista do Serviço Público, 56(3), 259-276.

Sheehan, N. T. (2005). Why old tools won't work in the "new" knowledge economy. Journal of Business 
Strategy, 26(4), 53-60. http://dx.doi.org/10.1108/02756660510608567

Stanko, M. A., Bohlmann, J. D., \& Molina-Castillo, F. J. (2013). Demand-side inertia factors and their benefits for innovativeness. Journal of the Academy of Marketing Science, 41(6), 649-668. http://dx.doi.org/10.1007/s11747-013-0332-y

Tapscott, D. (1996). Digital Economy: Promise and Peril in the Age of Networked Intelligence McGraw Hill. Inc, New York.

Von Bertalanffy, L. (1956). General system theory. General systems, 1(1), 11-17.

Whitaker, G. P. (1980). Coproduction: Citizen participation in service delivery. Public administration review, 240-246. http://dx.doi.org/10.2307/975377

Wood, D. P. (1996). Generalist Judges in a Specialized World. SMUL Rev., 50, 1755.

World Health Organization. (2002). The world health report 2002: reducing risks, promoting healthy life. World Health Organization.

\section{Copyrights}

Copyright for this article is retained by the author(s), with first publication rights granted to the journal.

This is an open-access article distributed under the terms and conditions of the Creative Commons Attribution license (http://creativecommons.org/licenses/by/4.0/). 